\title{
Bacterial lipopolysaccharide induces type 2 deiodinase in cultured rat astrocytes
}

\author{
Audrey Lamirand ${ }^{1,2,3}$, Martine Ramaugé ${ }^{1,2,3}$, Michel Pierre ${ }^{1,2,3}$ and Françoise Courtin ${ }^{1,2,3}$ \\ ${ }^{1}$ INSERM UMR 788, Stéroïdes, neuroprotection et neurogénération, 94275 Le Kremlin-Bicêtre cedex, France \\ ${ }^{2}$ INSERM UMR 854, Récepteurs, signalisations et physiopathologie thyroïdienne et de la reproduction, 94275 Le Kremlin-Bicêtre cedex, France \\ ${ }^{3}$ University Paris-Sud 11, 91405 Orsay cedex, France \\ (Correspondence should be addressed to F Courtin who is now at CNRS UMR 8200 Institut Gustave Roussy 39, Rue Camille Desmoulins, 94805 Villejuif, France; \\ Email: francoise.courtin@igr.fr)
}

\begin{abstract}
In the brain, $3,5,3^{\prime}$-triiodothyronine, which binds to the thyroid hormone receptor with high affinity, is locally generated from thyroxine by type 2 iodothyronine deiodinase (D2) expressed mainly in astrocytes and tanycytes. We have investigated the effects of bacterial lipopolysaccharide (LPS) on D2 in cultured rat astrocytes. LPS induced D2 activity with a lag-time of $4-8 \mathrm{~h}$ and a maximum at $24 \mathrm{~h}$. LPS also promoted D2 mRNA accumulation. Glucocorticoids enhanced both the basal and LPS-stimulated D2 activity and mRNA accumulation. These glucocorticoid effects were blocked by the glucocorticoid receptor antagonist RU486. Our results obtained with different specific signaling pathway inhibitors indicated that D2 induction by LPS required ERK and p38-MAPK signaling pathways. NF- $\kappa \mathrm{B}$ inhibitor
\end{abstract}

sulfasalazine blocked the effects of LPS on both D2 activity and mRNA accumulation. Hence, D2 induction by LPS appeared to implicate NF- $\kappa \mathrm{B}$ pathway in astrocytes. NF- $\mathrm{KB}$ responsiveness of the rat dio 2 gene was studied in astrocytes with dio2 $5^{\prime}$-flanking region promoter assays. The long form of the dio 2 promoter was transactivated by NF- $\kappa \mathrm{B}$. CCAAT/enhancer-binding protein $\beta$, which is upregulated by LPS in astrocytes, increased the transcriptional activity of the dio 2 promoter in its long or truncated forms containing CCAATs. Our observations, which demonstrate D2 induction by LPS in astrocytes and specify some characteristics of $\mathrm{D} 2$ induction mechanism, support the possible implication of brain D2 in adaptative responses to an infectious stress.

Journal of Endocrinology (2011) 208, 183-192

\section{Introduction}

Type 2 iodothyronine deiodinase (D2) catalyzes the $5^{\prime}$-deiodination of thyroxine $\left(\mathrm{T}_{4}\right)$ into the active form of thyroid hormones, 3,5,3'-triiodothyronine $\left(\mathrm{T}_{3}\right.$; Bianco et al. 2002, Gereben et al. 2008). Notably, in the brain most $T_{3}$ is produced locally by D2 (Crantz et al. 1982), which is primarily expressed in astrocytes and tanycytes that line the third ventricle in the mediobasal hypothalamus (GuadanoFerraz et al. 1997, Tu et al. 1997). Bacterial lipopolysaccharide (LPS) rapidly and markedly increases D2 activity and mRNA in the mediobasal hypothalamus (Fekete et al. 2004), independently of the LPS-induced fall in serum thyroid hormone levels (Fekete et al. 2005). This D2 induction by LPS in tanycytes and the resulting local increase in $\mathrm{T}_{3}$ production could be implicated in the suppression of the hypothalamic-pituitary-thyroid axis during peripheral bacterial infection (Fekete et al. 2004, 2005). Because the hypothalamic-pituitary-adrenal axis is markedly upregulated during infection (Tilders et al. 1994), the role of corticosterone has been studied in D2 induction by LPS in tanycytes in vivo (Sanchez et al. 2008). Administering high doses of corticosterone fails to mimic the LPS-induced increase in dio 2 gene expression in the mediobasal hypothalamus (Sanchez et al. 2008), indicating that mechanisms other than adrenal activation are involved. On the other hand, i.p. injection of LPS in rats increased D2 activity in the cerebral cortex (Fekete et al. 2004). D2 induction in astrocytes has been also observed after traumatic brain injury and brain focal ischemia (Zou et al. 1998, Margaill et al. 2005). These brain injuries are associated with acute inflammation (Lucas et al. 2006). D2 in rat cultured astrocytes is regulated by multiple factors including selenium, thyroid hormone, cAMP, phorbol ester tetradecanoylphorbol-13-acetate (TPA), growth factors, glucocorticoids, TSH, hypoxia, and oxidant stress (Courtin et al. 2005, Lamirand et al. 2007, 2008). However, LPS effects on D2 have not yet been tested in primary cultured astrocytes although LPS increases D2 activity in a mesothelioma cell line and in H4 glioma cells (Zeold et al. 2006, Freitas et al. 2010).

$\mathrm{NF}-\kappa \mathrm{B}$ is a transcription factor which is classically involved in LPS signaling pathways (Chen \& Greene 2004). An NF- $\mathrm{BB}$ inhibitor, i.e. sulfasalazine, partially inhibits LPS-induced D2 activity in human mesothelioma cells (Zeold et al. 2006). In HC11 and HEK-293 cells, p65 NF- $\kappa B$ markedly increased 
expression of both rat and human dio 2 genes as analyzed by promoter assays (Fekete et al. 2004). Human dio 2 promoter was more sensitive to $\mathrm{p} 65 \mathrm{NF}-\kappa \mathrm{B}$ than the rat dio 2 promoter (150- vs 3-fold increase) in HC11 cells. Recent findings have underlined the existence of an NF- $\mathrm{BB}$-binding site with transactivation potency of the p65 subunit of $N F-\kappa B$ in the promoter of the human dio 2 gene in HC11 cells (Zeold et al. 2006). Other cytokine mediators, such as signal transducer and activator of transcription-3 (STAT3) or -5 (STAT5), did not induce transcription of the dio 2 gene (Zeold et al. 2006). Other transcription factors, such as CCAAT/enhancerbinding proteins (C/EBPs), have not been studied although $\mathrm{C} / \mathrm{EBPs}$ are implicated in activation of LPS-inducible gene expression in different cells including astrocytes (Sweet \& Hume 1996, Kelicen \& Tindberg 2004).

We examined the effect of LPS on D2 activity and its mRNA accumulation in primary cultures of rat astrocytes in order to explore the regulation of D2 by LPS in astrocytes. Induction of D2 by LPS in astrocytes was studied in the presence or absence of glucocorticoids. We examined D2 induction by LPS in the presence of inhibitors of p38-MAPK and ERK pathways that are activated by LPS in astrocytes (Bhat et al. 1998). We also studied the effects of inhibitor of $\mathrm{NF}-\kappa \mathrm{B}$ sulfasalazine. Finally, we tested the ability of the transcription factors $\mathrm{NF}-\kappa \mathrm{B}$ and $\mathrm{C} / \mathrm{EBPs}$ to act on the promoter of the rat dio 2 gene in astrocytes.

\section{Materials and Methods}

\section{Materials and animals}

$\mathrm{T}_{4}, \mathrm{~T}_{3}$, dithiothreitol (DTT), N-acetyl cysteine (NAC), SB203580, cortisol, dexamethasone, RU486, LPS purified by phenol extraction from Escherichia coli strain 055:B5, sulfasalazine, L-NAME, and antibiotics were obtained from Sigma Aldrich Co. U0126 was purchased from Biomol (Plymouth Meeting, PA, USA). Sodium selenite was purchased from Merck. Exgen500 was obtained from Euromedex (Souffelweyersheim, France). $\left[{ }^{125} \mathrm{I}_{3} \mathrm{~T}_{3}\right.$ $(3 \mathrm{mCi} / \mu \mathrm{g})$ and $\left[{ }^{125} \mathrm{I}\right] \mathrm{T}_{4}(1.5 \mathrm{mCi} / \mu \mathrm{g})$ were purchased from Amersham International. Sprague-Dawley rats were purchased from Iffa-Credo (L'Albresle, France). FCS and culture media were obtained from Life Technologies. Culture dishes were obtained from Nunclon (Roskilde, Denmark).

\section{Cell culture conditions}

Brains were removed from 2-day-old Sprague-Dawley rats and cleaned of meninges and blood vessels. The two cerebral hemispheres were then dissociated to form a cell suspension by a passage through a nylon mesh $(82 \mu \mathrm{m}$ pore size) into $40 \mathrm{ml}$ DMEM supplemented with $6 \mathrm{~g} / 1$ glucose, $2.4 \mathrm{~g} / 1$ sodium bicarbonate, antibiotics $(100 \mathrm{U} / \mathrm{ml}$ penicillin, $100 \mu \mathrm{g} / 1$ streptomycin, and $0 \cdot 25 \mu \mathrm{g} / 1$ amphotericin B), and $10 \%$ FCS (DMEM/FCS). Aliquots $(3 \mathrm{ml})$ of this cell suspension were placed in $60 \mathrm{~mm}$ Petri dishes and the cultures were maintained at $37^{\circ} \mathrm{C}$ under $5 \% \mathrm{CO}_{2}, 95 \%$ air, and more than $90 \%$ humidity. The medium was changed every 2-3 days until cells reached confluency at $\sim 10$ days. At this stage, the DMEM/FCS was removed, and the cells were washed with a chemically defined medium that consisted of a 1:1 mixture of DMEM and Ham's F-12 medium supplemented with $4.5 \mathrm{~g} / 1$ glucose, $1.8 \mathrm{~g} / 1$ sodium bicarbonate, and the antibiotics listed above (DMEM/F12). The cells were then cultured for 3 additional days in DMEM/F12 supplemented with $30 \mathrm{nM}$ sodium selenite, $10 \mu \mathrm{g} / \mathrm{ml}$ insulin, and $10 \mu \mathrm{g} / \mathrm{ml}$ transferrin followed by 1 additional day in DMEM/F12 supplemented with $30 \mathrm{nM}$ sodium selenite, $10 \mu \mathrm{g} / \mathrm{ml}$ transferrin, and eventually $1 \mu \mathrm{M}$ of cortisol. Under these conditions, more than $90 \%$ of the cells contained immunoreactive glial fibrillary acidic protein, a specific marker of astrocytes (Esfandiari et al. 1994, Pallud et al. 1999). Astrocytes were treated with the test agents for the times and the concentrations indicated in each experiment.

\section{Plasmids}

Reporter construct rdio2\#1 (Gereben et al. 2001) corresponds to the chloramphenicol acetyl-transferase (CAT) reporter vector, pOCAT2, containing the rat dio 2 promoter $\left(\sim 3.8 \mathrm{~kb}\right.$ rdio $25^{\prime}-\mathrm{FR}$ and $\sim 600 \mathrm{bp} \mathrm{rD} 25^{\prime}$-UTR). The two truncated $\mathrm{rdio} 2 \# 3$ and $\mathrm{rdio} 2 \# 4$ constructs contain respectively 658 or $83 \mathrm{bp} 5^{\prime}$ to the rdio 2 Transcription Start Site (TSS) and the same portion of the $5^{\prime}$-UTR sequence (Gereben et al. 2001). These plasmids were gifts from P R Larsen. We also constructed, using SacI and BamHI restriction enzymes, a short reporter construct, rdio2\#5 corresponding to $37 \mathrm{bp} 5^{\prime}$ upstream of the $5^{\prime}-\mathrm{UTR}$ sequence; p50 and p65 subunits of $N F-\kappa B$ subcloned in the pcDNA3.1 expression vector and $\mathrm{C} / \mathrm{EBP} \alpha, \mathrm{C} / \mathrm{EBP} \beta$, and $\mathrm{C} / \mathrm{EBP} \delta$ subcloned in the expression vector $\mathrm{pREP} 4$ were obtained from M Raymondjean (Antonio et al. 2002). Liver activating protein (LAP) or C/EBP $\beta$, liver inhibiting protein (LIP), and C/EBP-homologous protein (CHOP) were subcloned in the expression vector $\mathrm{pREP} 4$ and were gifts from M Pomerance (Pomerance et al. 2005).

\section{Transient transfection, luciferase, and CAT assays}

Aliquots $(2 \mathrm{ml})$ of the astrocyte suspension were placed into six-well plate and the cultures were maintained at $37^{\circ} \mathrm{C}$ under $5 \% \mathrm{CO}_{2}, 95 \%$ air, and more than $90 \%$ humidity. The medium was changed the day after and on day 6. Transient transfection was performed on day 7 with Exgen500 (Euromedex) according to the manufacturer's instructions. Cells were cotransfected with $700 \mathrm{ng} /$ well of rdio2\#1, rdio2\#3, rdio2\#4, or rdio2\#5, $200 \mathrm{ng} /$ well of pGL2SV40-luciferase expression vector, and $100 \mathrm{ng} /$ well of the expression plasmids. These amounts were defined by previous dose-response studies for each plasmid. In experiments with pREP4-LIP, cells were also cotransfected with $500 \mathrm{ng} /$ well 
of empty pREP4 vector or pREP4-LIP. In experiments with pREP4-CHOP, cells were also cotransfected with $100 \mathrm{ng} /$ well of empty pREP4 vector or pREP4-CHOP. One day after transfection, cells were incubated with DMEM containing 10\% charcoal-treated FCS. Transfected cells were used $48 \mathrm{~h}$ after transfection. Luciferase activity was used to normalize the transfection efficiency in cultured dishes. The luciferase assay was assessed using a lumat luminometer (Berthold Technologies, Bad Wildbad, Germany) as previously described (Massaad et al. 2000a). The CAT activity was determined by using the two-phase assay (Massaad et al. 2000b). Each construct was transfected at least three times.

\section{D2 $m R N A$ quantification by real-time PCR}

Total RNA was extracted using GenElute mammalian total RNA miniprep kit (Sigma Aldrich Co.) and was quantified by the absorption at $260 \mathrm{~nm}$. Subsequently, cDNA was synthesized by reverse transcription using the M-MLV reverse transcriptase system (Invitrogen Co.). The cDNAs were amplified in a real-time PCR using the Taqman gene expression assay with the designing primers for D2 and 18S rRNA as an endogenous control (Applied Biosystems, Foster City, CA, USA). The generated D2 and 18S cDNA levels were measured using the ABI Prism 7000 sequence detection system and the relative standard curve method. Briefly, all genes were quantified from a standard curve representing a five-point serial dilution of mixed experimental and control cDNA, which were analyzed and used as calibrators of the quantification of the product generated in the exponential phase of the amplification curve. Both standards and samples were run in duplicate. Typically, the equivalent cDNA of 20 ng RNA was used for the real-time PCR of each sample. $R^{2}$ was $>0.99$ for all standard curves.

\section{D2 and type 3 iodothyronine deiodinase assays}

At the time of harvesting, the medium was aspirated, and the cells were rinsed with $3 \mathrm{ml}$ ice-cold PBS on ice. Culture dishes containing the cells were then frozen at $-80^{\circ} \mathrm{C}$ for later processing and analysis. This involved placing the plates on ice, scraping the content of each dish into $0.4 \mathrm{ml}$ sample buffer (20 mM HEPES, $2 \mathrm{mM}$ DTT, and $0.25 \mathrm{M}$ sucrose, $\mathrm{pH}$ $7 \cdot 4$ ), and disrupting the cells by sonication. D2 activity was measured by incubating aliquots of the cell sonicate in an $80 \mu \mathrm{l}$ final volume of $20 \mathrm{mM}$ HEPES, $\mathrm{pH} 7 \cdot 4$, containing $20 \mathrm{mM} \mathrm{DTT}, 50 \mathrm{nM} \mathrm{T}_{3}$, and $1 \mathrm{nM}\left[{ }^{125} \mathrm{I} \mathrm{T}_{4}\right.$ for $20-60 \mathrm{~min}$ at $37^{\circ} \mathrm{C}$. Addition of $50 \mathrm{nM} \mathrm{T}_{3}$ prevented 5-deiodination of both $\left[{ }^{125} \mathrm{I}\right] \mathrm{T}_{4}$ and $\mathrm{D} 2$-generated $\left[{ }^{125} \mathrm{I}\right] \mathrm{T}_{3}$ into $\left[{ }^{125} \mathrm{I}\right] 3,3^{\prime}, 5^{\prime}-$ triiodothyronine (reverse $\mathrm{T}_{3}$ ) and $\left[{ }^{125} \mathrm{I}\right] 3,3^{\prime}$-diiodothyronine $\left(3,3^{\prime}-\mathrm{T}_{2}\right)$ respectively, according to the previous in vitro studies on type 3 iodothyronine deiodinase (D3) activity in cultured astrocytes (Esfandiari et al. 1992). Reactions were stopped by adding $10 \mu \mathrm{l}$ of $10 \mathrm{M} \mathrm{NH}_{4} \mathrm{OH}$ containing $10 \mu \mathrm{M}$ iodide, $10 \mu \mathrm{M} \mathrm{T}_{3}$, and $10 \mu \mathrm{M} \mathrm{T}_{4}$. The $\left[{ }^{125} \mathrm{I} \mathrm{T}_{3}\right.$ produced was separated from $\left[{ }^{125} \mathrm{I}\right] \mathrm{T}_{4}$ by descending paper chromatography
(Courtin et al. 1986). Then, the radioactive products were counted for determination of D2 activity, expressed as femtomoles of $\mathrm{T}_{3} / \mathrm{min}$ per mg protein. Kinetic analysis was performed in sonicates of LPS-treated cells using 0.05-2 nM $\left.{ }^{125} \mathrm{I}\right] \mathrm{T}_{4}$ as substrate and $20 \mathrm{mM}$ DTT as cofactor. For D3 activity assays, homogenates were incubated at $37^{\circ} \mathrm{C}$ for $60 \mathrm{~min}$ in a final volume of $80 \mu \mathrm{l}$ containing $20 \mathrm{mM}$ HEPES buffer $(\mathrm{pH} 7 \cdot 4), 20 \mathrm{mM}$ DTT, and $5 \mathrm{nM}\left[{ }^{125} \mathrm{I}\right] \mathrm{T}_{3}$. Reactions were stopped by adding $10 \mu \mathrm{l}$ of $10 \mathrm{M} \mathrm{NH}_{4} \mathrm{OH}$ containing $10 \mu \mathrm{M} \mathrm{T} \mathrm{T}_{3}$ and $10 \mu \mathrm{M} \mathrm{T}$. The $\left[{ }^{125} \mathrm{I}\right] 3,3^{\prime}-\mathrm{T}_{2}$ produced was separated from $\left[{ }^{125} \mathrm{I}\right] \mathrm{T}_{3}$ by descending paper chromatography (Courtin et al. 1986). Then, the radioactive products were counted for determination of D3 activity, expressed as femtomoles of $3,3^{\prime}-\mathrm{T}_{2} / \mathrm{min}$ per $\mathrm{mg}$ protein. For D2 and D3 assays, deiodination was linear with respect to both protein concentration and incubation time and the quantity of protein assayed was adjusted to ensure that $<30 \%$ of the substrate was consumed.

\section{Protein determination}

The protein content of cell sonicates was determined by the method of Bradford (Bradford 1976) using BSA as standard.

\section{Statistical analysis}

Statistical differences between the groups were determined using a commercially available program (GraphPad Prism 3.0; GraphPad, Inc., San Diego, CA, USA). Data were processed using one-way or two-way ANOVA, followed by Bonferroni post hoc test. Student's t-test was also used. Statistical significance was noted at $P<0 \cdot 05$.

\section{Results}

\section{Effects of LPS on D2 activity and $m R N A$ expression}

Primary cultures of rat astrocytes, which were maintained for 2 days in a chemically defined medium containing cortisol as commonly used (Morrison \& de Vellis 1981, Pallud et al. 1999), were treated with LPS. We found that the LPS stimulation of D2 activity was time- and dose-dependent (Fig. 1A and B). The effect of $1 \mu \mathrm{g} / \mathrm{ml}$ LPS was visible after $4 \mathrm{~h}$ (significantly different using a $t$-test, $P<0 \cdot 001$ ) and reached a maximum at $24 \mathrm{~h}$. This delayed action of LPS suggests an indirect effect. D2 activity was increased after a $10 \mathrm{~h}$ treatment with LPS from $0 \cdot 1 \mu \mathrm{g} / \mathrm{ml}$ (significantly different using a $t$-test, $P<0 \cdot 001)$ and was maximal for $1 \mu \mathrm{g} / \mathrm{ml}$, the concentration that we usually use. The LPSinduced D2 activity was not inhibited by $1 \mathrm{mM}$ PTU and had a Michaelis constant $\left(K_{\mathrm{m}}\right)$ for $\mathrm{T}_{4}$ around $1 \mathrm{nM}$ (not shown). These enzymatic properties of D2 activity induced by LPS were characteristic of D2 (Bianco et al. 2002), as previously reported for other inducers in cultured astrocytes (Courtin et al. 1989, 2005). We also found that in the same 

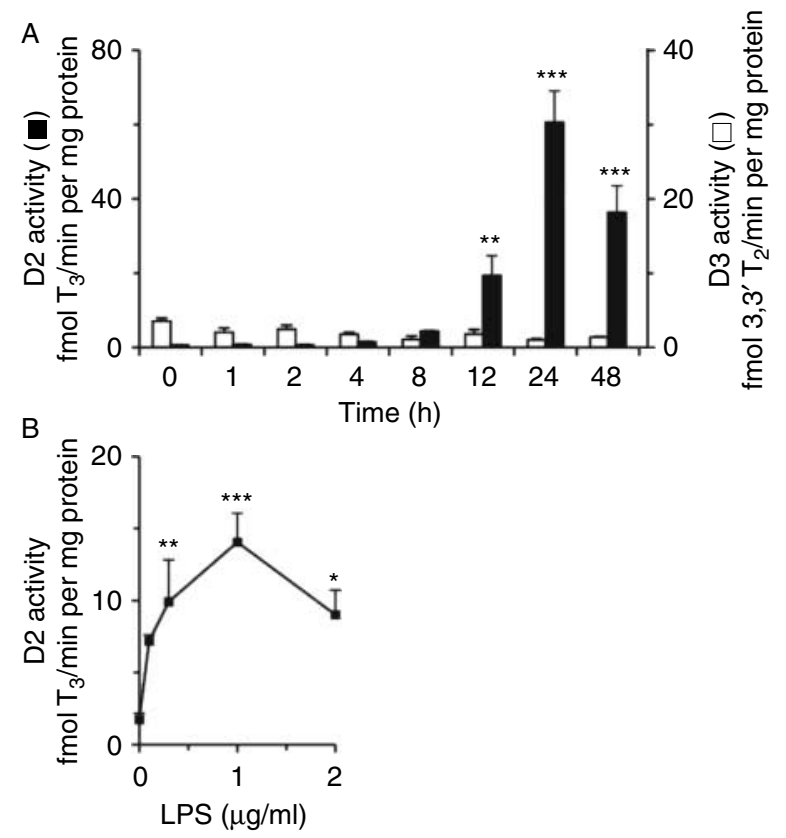

Figure 1 LPS increases D2 activity without affecting D3 activity. Astrocytes were cultured in the presence of $1 \mu \mathrm{M}$ cortisol for the last $24 \mathrm{~h}$. (A) Astrocytes were treated with $1 \mu \mathrm{g} / \mathrm{ml}$ LPS for different times before harvesting. D2 (black bars) and D3 (white bars) activities were measured as described in section 'Materials and Methods'. (B) Astrocytes were treated with several concentrations of LPS for $10 \mathrm{~h}$ before harvesting. Data are the means \pm s.D. of results obtained from three dishes (one-way ANOVA analysis; LPS-treated versus the controls without treatment, ${ }^{*} P<0 \cdot 05 ; * * P<0 \cdot 01$; ${ }^{* * *} P<0 \cdot 001$ ).

culture medium containing cortisol, LPS increased D2 mRNA accumulation (Fig. 2B) indicating a pretranslational step of $\mathrm{D} 2$ regulation by LPS.

Both the basal level of D2 activity $(0 \cdot 4-2$ femtomoles of $\mathrm{T}_{3} / \mathrm{min} \times \mathrm{mg}$ protein) and its LPS stimulation after $12 \mathrm{~h}(8-$ to 30-old) varied from one cell preparation to another as previously reported (Courtin et al. 1989). These variations could also be explained by the different efficiencies of LPS batches or their stabilities at $4{ }^{\circ} \mathrm{C}$.

D3 activity, which also regulates cerebral $\mathrm{T}_{3}$ concentration by catalyzing the 5 -deiodination of thyroid hormones into inactive metabolites (Bianco et al. 2002, Courtin et al. 2005), was not induced by $1 \mu \mathrm{g} / \mathrm{ml}$ LPS in cultured astrocytes (Fig. 1A).

\section{Role of glucocorticoids in LPS action}

Glucocorticoids are powerful anti-inflammatory agents that suppress many effects of LPS in various systems including astrocytes (Kozuka et al. 2007). We therefore studied the effects of LPS treatment for $12 \mathrm{~h}$ on D2 activity (Fig. 2A) and D2 mRNA (Fig. 2B) in astrocytes cultured in the absence or presence of $1 \mu \mathrm{M}$ cortisol. LPS increased D2 activity and D2 mRNA both in the absence and presence of cortisol. D2 activity was fourfold increased by cortisol in cells in basal conditions as well as in cells treated with LPS (Fig. 2A). D2 mRNA was also threefold increased by cortisol in cells treated with LPS (Fig. 2B). In basal conditions, D2 mRNA was twofold increased by cortisol that appeared significantly different $(P<0 \cdot 01)$ by $t$-test analysis (not shown). We checked that $10 \mathrm{nM}$ dexamethasone, a synthetic unmetabolizable glucocorticoid, which binds the glucocorticoid receptor and mineralocorticoid receptor, also enhanced D2 activity and $\mathrm{mRNA}$ expression in LPS-treated or untreated astrocytes (Fig. 2C and D). We specified the mechanism of action of glucocorticoids by studying the effect of $1 \mu \mathrm{M}$ RU486, a glucocorticoid receptor antagonist, on the enhancement of D2 by dexamethasone. We found that RU486 alone had no effect on D2 activity or mRNA and did not increase the action of LPS. Furthermore, RU486 suppressed the effect of dexamethasone on basal D2 activity and mRNA accumulation and also on LPS-induced D2 activity or

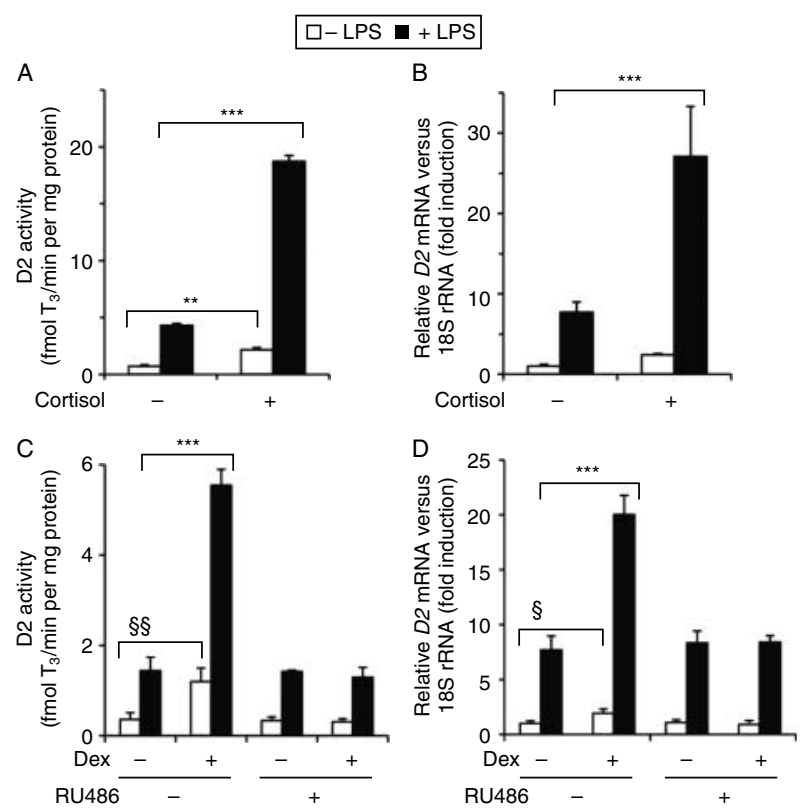

Figure 2 D2 induction by LPS is enhanced by glucocorticoids. ( $A$ and $B$ ) Astrocytes were cultured in the absence or presence of $1 \mu \mathrm{M}$ cortisol for the last $24 \mathrm{~h}$. Astrocytes were untreated (white bars) or treated for $12 \mathrm{~h}$ with $1 \mu \mathrm{g} / \mathrm{ml}$ LPS (black bars) before harvesting. D2 activity (A) and D2 mRNA accumulation (B) were measured as described in section 'Materials and Methods'. Data are the means \pm s.D. of the results obtained from three dishes (two-way ANOVA analysis; $\left.{ }^{* * *} P<0 \cdot 001 ;{ }^{* *} P<0 \cdot 01\right)$. (C and D) Astrocytes were cultured in the presence of vehicle $(0.1 \%$ ethanol) or in the presence of $10 \mathrm{nM}$ dexamethasone (Dex), $1 \mu \mathrm{M}$ RU486, or both agents for the last $24 \mathrm{~h}$. Astrocytes were treated for $12 \mathrm{~h}$ with $1 \mu \mathrm{g} / \mathrm{ml}$ LPS before harvesting. D2 activity (C) and D2 mRNA accumulation (D) were measured as described in section 'Materials and Methods'. Data are the means \pm s.D. of results obtained from three dishes (two-way ANOVA analysis; basal conditions with or without RU486 in the presence of dexamethasone versus in the absence of dexamethasone; ${ }^{\S} P<0 \cdot 01 ;{ }^{\S} P<0 \cdot 05$; LPS-treated conditions with or without RU486 in the presence of dexamethasone versus in the absence of dexamethasone, *** $P<0 \cdot 001)$. 


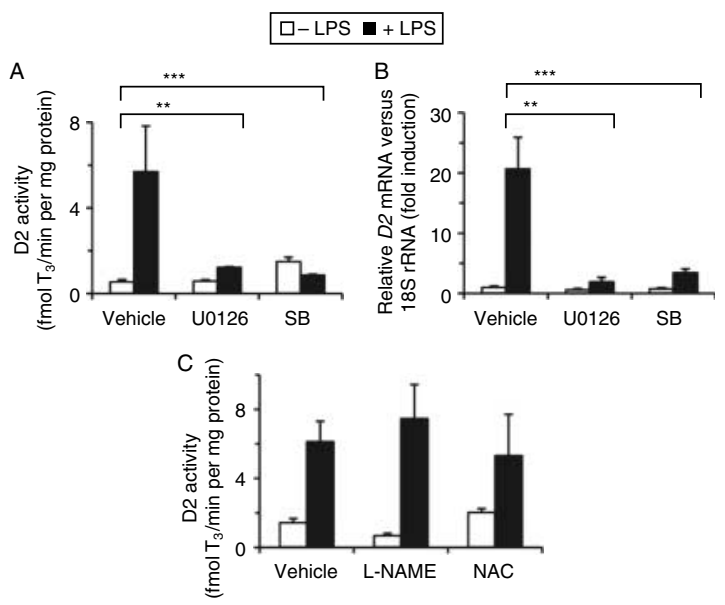

Figure 3 Implication of p38-MAPK and ERK pathways in D2 induction by LPS. Astrocytes were cultured in the presence of $1 \mu \mathrm{M}$ cortisol for the last $24 \mathrm{~h}$. Cells were untreated (white bars) or treated for $12 \mathrm{~h}$ with $1 \mu \mathrm{g} / \mathrm{ml}$ LPS (black bars) before harvesting. (A and B) Implication of p38-MAPK and ERK pathways; $0 \cdot 1 \%$ DMSO (vehicle), $5 \mu \mathrm{M}$ SB203580 (SB), or $5 \mu \mathrm{M} \cup 0126$ were added $20 \mathrm{~min}$ before LPS. (C) Absence of implication of $\mathrm{H}_{2} \mathrm{O}_{2}$ or NO. L-NAME $(0.5 \mathrm{mM})$ or $20 \mathrm{mM} \mathrm{N}$-acetyl cysteine (NAC) were added $20 \mathrm{~min}$ before LPS. D2 activity (A and C) and D2 mRNA accumulation (B) were measured as described in section 'Materials and Methods'. Data are the means \pm s.D. of the results obtained from three dishes (two-way ANOVA analysis; different signaling pathway inhibitors in the presence or absence of LPS versus vehicle in the presence or absence of LPS, $\left.* * * P<0 \cdot 001 ;{ }^{* *} P<0 \cdot 01\right)$.

mRNA accumulation. Thus, these effects of glucocorticoids implicate their binding to the glucocorticoid receptor.

\section{Implication of MAP kinases in D2 induction by LPS}

Since the activation of MAP kinases is involved in LPS signaling in astrocytes (Bhat et al. 1998, Lee et al. 2003, Shin et al. 2007), LPS effects on D2 activity and mRNA accumulation were studied in the presence of U0126 and SB203580, inhibitors respectively of ERK and p38-MAPK pathways (Fig. 3A and B). The effects of LPS (12 h treatment) on $D 2$ mRNA accumulation and activity were inhibited by U0126 and SB203580. Thus, activation of ERK and p38-MAPK is certainly at stake in the effects of LPS.

Since production of reactive oxygen species (ROS) and nitric oxide (NO) are classical responses to LPS treatment, including in astrocytes (Bhat et al. 1998, 2002, Pawate et al. 2004, Rada \& Leto 2008), we assessed their hypothetical role in D2 activation by LPS. NAC, a powerful antioxidant, has been previously shown to diminish in astrocytes the effects of $\mathrm{H}_{2} \mathrm{O}_{2}$, which increases D3 and inhibits D2 (Lamirand et al. 2008). NAC $(20 \mathrm{mM})$ had no effect on the activation of $\mathrm{D} 2$ activity by LPS (Fig. 3C). This eliminated a role of $\mathrm{H}_{2} \mathrm{O}_{2}$ in the effect of LPS on D2. L-NAME, an inhibitor of NO synthase (NOS), did not affect LPS-induced D2 activity, showing that $\mathrm{NO}$ was not involved in this regulation.
Implication of NF-KB in D2 induction by LPS and its effect on the rat dio2 promoter in rat astrocytes

To examine the implication of NF- $\kappa \mathrm{B}$ signaling pathway in LPS-induced D2 in rat astrocytes, effects of LPS on D2 activity and mRNA accumulation were studied in the presence of NF- $\kappa \mathrm{B}$ inhibitor sulfasalazine (Fig. $4 \mathrm{~A}$ and B). This NF- $\kappa \mathrm{B}$ inhibitor has been previously shown to partially block LPS-induced D2 activity in mesothelioma cells (Zeold et al. 2006). LPS-induced increase in $\mathrm{D} 2$ activity was blocked by sulfasalazine in the presence of cortisol (Fig. 4A). We also showed the inhibition by sulfasalazine of LPS-induced D2 mRNA accumulation (Fig. 4B). Sulfasalazine also caused a 65 and $80 \%$ reduction in LPS-induced D2 activity and mRNA accumulation in the absence of cortisol. These data suggest that the LPS/NF- $\kappa \mathrm{B}$ signaling pathway is able to stimulate D2 expression in rat astrocytes cultured in the presence or absence of cortisol.

Since NF- $\kappa \mathrm{B}$ has been shown to be able to activate transcription of dio 2 promoter in different cell lines including glioblastoma (Fekete et al. 2004, Zeold et al. 2006), we also
A
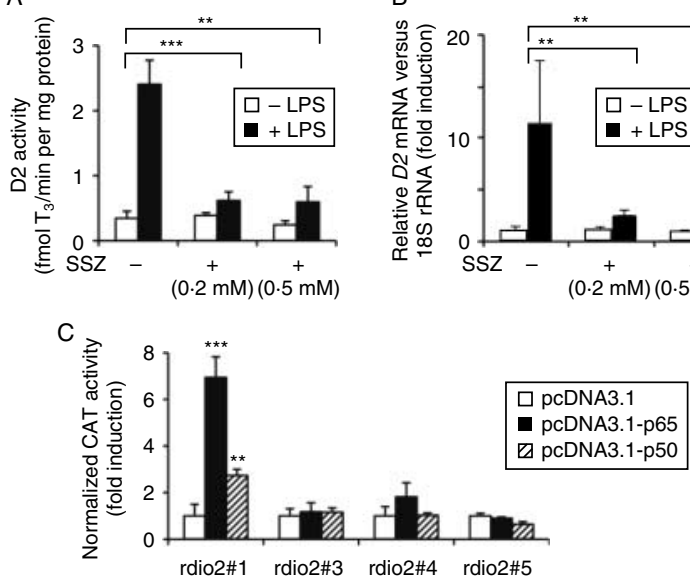

Figure 4 Implication of NF- $\kappa$ B pathway in D2 induction by LPS. Activation of the rat dio2 promoter in astrocytes by p65 and p50

NF- $\kappa$ B. (A and B) Astrocytes were cultured in the presence of $1 \mu \mathrm{M}$ cortisol for the last $24 \mathrm{~h}$. Cells were untreated (white bars) or treated for $12 \mathrm{~h}$ with $1 \mu \mathrm{g} / \mathrm{ml}$ LPS (black bars) before harvesting; $0 \cdot 1 \%$ DMSO (vehicle), sulfasalazine (SSZ) at 0.2 or $0.5 \mathrm{mM}$ were added 20 min before LPS. D2 activity (A) and D2 mRNA accumulation (B) were measured as described in section 'Materials and Methods'. Data are the means \pm s.D. of the results obtained from three dishes (two-way ANOVA analysis; SSZ at different concentrations in the presence or absence of LPS versus vehicle in the presence or absence of LPS, $\left.{ }^{* * *} P<0 \cdot 001 ; * * P<0 \cdot 01\right)$. (C) The rdio2\#1, rdio2\#3, rdio $2 \# 4$, and rdio $2 \# 5$ constructs (containing respectively $3 \cdot 8 \mathrm{~kb}$, 658, 83 and 37 bp rat dio2 $5^{\prime}$-FR) were cotransfected with empty pcDNA3.1 vector, pcDNA3.1-p65, or pcDNA3.1-p50 for $48 \mathrm{~h}$. Normalized CAT activity was measured as described in section 'Materials and Methods' and expressed as fold induction of the empty pcDNA3.1 vector for each construct. Data are the means \pm S.D. of the results obtained from three dishes (two-way ANOVA analysis; cotransfection with pCDNA3.1 vector containing p65 or p50 versus the respective controls cotransfected with the empty pcDNA3.1 vector, $\left.{ }^{* *} P<0 \cdot 01 ;{ }^{* * *} P<0 \cdot 001\right)$. 


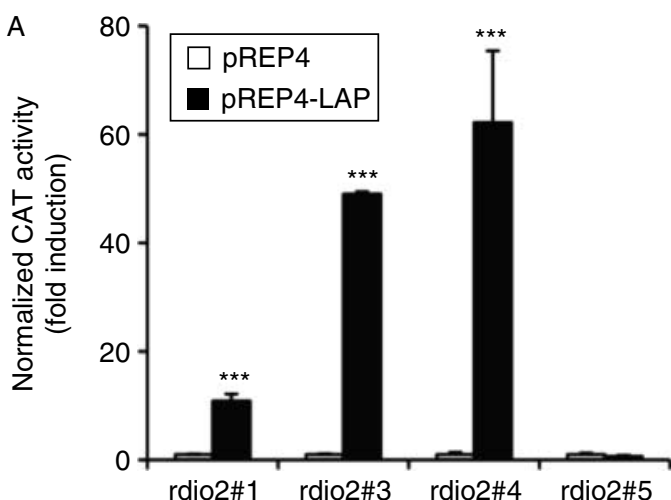

B
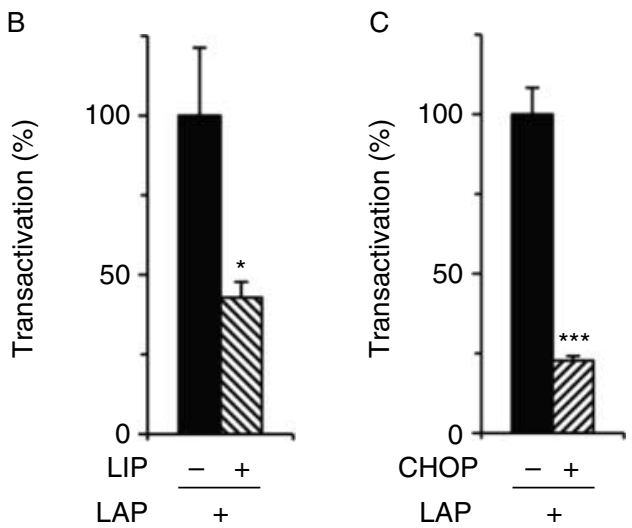

Figure $5 \mathrm{C} / \mathrm{EBP} \beta$ activates the rat dio2 promoter in astrocytes. (A) The rdio2 $\# 1$, rdio2 $\# 3$, rdio2 $\# 4$, and rdio2 $\# 5$ constructs (containing respectively $3.8 \mathrm{~kb}, 658,83$, and $37 \mathrm{bp}$ rat dio2 $5^{\prime}$-FR) were cotransfected with pREP4-LAP plasmid or empty pREP4 vector for $48 \mathrm{~h}$. Normalized CAT activity was measured as described in section 'Materials and Methods' and expressed as fold induction of empty pREP4 vector for each construct. Data are the means \pm s.D. of the results obtained from three dishes (two-way ANOVA analysis; cotransfection with pREP4 vector containing LAP versus the respective controls cotransfected with the empty pREP4 vector, $* * * P<0 \cdot 001$ ). (B and C) The rdio2\#4 construct was cotransfected with $100 \mathrm{ng}$ pREP4-LAP plasmid associated with $500 \mathrm{ng}$ empty pREP4 vector or pREP-LIP (B), or associated with 100 ng empty pREP4 vector or pREP-CHOP (C). Normalized CAT activity was measured as described in section 'Materials and Methods' and expressed as \% of transactivation when empty pREP4 vector was added with pREP4-LAP. Data are the means \pm S.D. of the results obtained from three dishes $(* P<0 \cdot 05 ; * * * P<0 \cdot 001$ when compared with control by Student's $t$-test).

checked the effect of this transcription factor on rat dio 2 promoter in our cultured rat astrocytes. In astrocytes, co-expression of $\mathrm{p} 65 \mathrm{NF}-\mathrm{\kappa B}$ with the $3 \cdot 8 \mathrm{~kb}$ form of the rat dio 2 promoter (rdio2\#1) led to a sevenfold increase in the transcriptional activity (Fig. 4C). The other component of $\mathrm{NF}-\kappa \mathrm{B}, \mathrm{p} 50$, led to a threefold induction of the rdio2\#1 construct transcriptional activity. The truncated promoters (rdio2\#3, rdio2\#4, and rdio2\#5) remained unresponsive. LPS did not increase the transcription activity of the transfected rat dio 2 promoter in cultured astrocytes (not shown). LPS was also unable to increase the transcriptional activity of transfected IL6 promoter in cultured astrocytes (not shown). Finally, LPS did not increase endogenous D2 activity in the transfected astrocytes (not shown), suggesting that these transfection conditions interfere with LPS signaling in astrocytes.

\section{Effect of C/EBPs on the rat dio2 promoter in rat astrocytes}

We also examined the action of other transcription factors, $\mathrm{C} / \mathrm{EBPs}$ that are classically known to be involved in gene expression activation by LPS. The co-expression of LAP $(\mathrm{C} / \mathrm{EBP} \beta)$ very strongly induced the $\mathrm{D} 2$ promoter (long and truncated forms containing CCAAT, i.e. rdio2\#1, rdio2\#3 and rdio2\#4) (Fig. 5A). Co-expression of LAP did not affect the $37 \mathrm{bp}$ minimal promoter (rdio2\#5), which did not contain CCAAT, a putative C/EBP-responsive element. Overexpression of $\mathrm{C} / \mathrm{EBP} \alpha$ or $\mathrm{C} / \mathrm{EBP} \delta$ also strongly activated rdio2\#1, rdio2\#3, and rdio2\#4 (not shown). We also checked that LIP and CHOP, which are competitive inhibitors of LAP by binding to the regulatory CCAAT sequences, effectively suppressed these effects (Fig. 5B and C).

\section{Discussion}

In the present work, we show for the first time that the bacterial LPS induces type 2 deiodinase in primary cultures of rat astrocytes. D2 activity induction by LPS observed in cultured astrocytes after a lag of $4-8 \mathrm{~h}$ involves D2 mRNA increase. D3 was not induced by LPS in cultured rat astrocytes. Previously, LPS was shown to induce D2 activity in MSTO-211H cells (Zeold et al. 2006) but not in GH3 cells (Baur et al. 2000). Very recently, LPS was reported to induce D2 in H4 glioma cells (Freitas et al. 2010).

Interestingly, the D2 induction by LPS was increased by cortisol or dexamethasone, acting through the glucocorticoid receptor because dexamethasone effect was blocked by the glucocorticoid receptor antagonist RU486 (Jung-Testas \& Baulieu 1984). Basal D2 activity and mRNA were also increased by glucocorticoids as previously reported in astrocytes for D2 activity (Courtin et al. 1989). LPS-induced D2 increase in astrocytes was inhibited by the NF- $\mathrm{KB}$ inhibitor sulfasalazine, indicating the implication of the $N F-\kappa B$ pathway in the presence or absence of glucocorticoids. Consequently, glucocorticoids do not inhibit NF- $\mathrm{KB}$ pathway implicated in D2 induction by LPS. However, glucocorticoids block IL6 expression by LPS in astrocytes (Grimaldi et al. 1998) as we also checked in our culture conditions (not shown), allowing one to discard a role for IL6 in the LPS effects on D2 in cultured astrocytes. Repression of NF- $\kappa \mathrm{B}$ activity by glucocorticoids has indeed been reported to depend on promoter and cell type (De Bosscher et al. 2003). Moreover, emerging literature suggests that glucocorticoid pro-inflammatory effects can co-exist with their anti-inflammatory properties, particularly in the central nervous system (Sorrells et al. 2009). D2 induction by TPA 
is also strongly increased by glucocorticoids in astrocytes (Courtin et al. 1989). However, TPA-induced D2 activity was not inhibited by NF-KB inhibitor sulfasalazine (not shown). D2 induction by LPS is shown in this study to require the ERK and p38-MAPK pathways, which have been demonstrated to be activated by LPS in astrocytes (Bhat et al. 1998, Lee et al. 2003, Shin et al. 2007). Interestingly, MAPK pathways can be activated by $\mathrm{H}_{2} \mathrm{O}_{2}$ (Tournier et al. 1997, Lennon et al. 2002) and LPS plus interferon $\gamma$ can increase NOS through ROS production and MAPK pathways (Pawate et al. 2004). However, D2 induction by LPS was not affected by NAC, which is a powerful antioxidant. This indicates that D2 induction by LPS is independent of $\mathrm{H}_{2} \mathrm{O}_{2}$ production and suggests another activating mechanism than $\mathrm{H}_{2} \mathrm{O}_{2}$ for ERK and p38-MAPK pathways. Morever, LPS-induced D2 activity was not affected by L-NAME, a NOS inhibitor, whereas NO and NOS were shown, in astrocytes, to be implicated in regulation by LPS of some genes, including UGTA16 (Heurtaux et al. 2006). D2 induction by LPS is therefore independent of NO production, which was shown to be blocked by glucocorticoids (Kozuka et al. 2007).

The increase in LPS-induced D2 by glucocorticoids in astrocytes might be physiologically significant because glucocorticoids are increased in vivo by various type of stress, including infectious stress (Sternberg 2001). LPS can enter the brain by crossing the blood-brain barrier and bind some receptors that are notably localized in astrocytes (Bowman et al. 2003). In mediobasal hypothalamus including the median eminence, a structure particularly sensitive to LPS as it is devoid of blood-brain barrier (Zlokovic 1995), the LPS-induced D2 mRNA is not mediated by the associated increase in glucocorticoids (Sanchez et al. 2008). However, this does not exclude a glucocorticoid contribution to the effect of LPS as observed in cultured astrocytes. Moreover, D2 is predominantly expressed in tanycytes and not in astrocytes in the mediobasal hypothalamus (Guadano-Ferraz et al. 1997, Tu et al. 1997, Fekete et al. 2004, Sanchez et al. 2008), bringing a potential explanation of the difference observed in glucocorticoid effects.

Since NF- $\kappa B$ inhibitor sulfasalazine inhibited LPS-induced D2 increase in astrocytes, we also checked that NF- $\kappa \mathrm{B}$, a transcription factor classically known to be involved in gene expression activation by LPS, was able to stimulate dio2 promoter in astrocytes. NF- $\mathrm{KB}$ induction of human and rat dio 2 promoter has been previously observed in human cell lines HC11 and HEK-293 (Fekete et al. 2004, Zeold et al. 2006). We observed a sevenfold transactivation of rat dio 2 promoter by $\mathrm{p} 65 \mathrm{NF}-\kappa \mathrm{B}$ in astrocytes, a transactivation of the same order as that previously described (threefold) for the rat dio 2 promoter in HC11 cells (Fekete et al. 2004). Among all forms of promoter we tested, only the rdio2\#1, which is the longest construct $(3.8 \mathrm{~kb})$, responded to p65 and p50, excluding the putative NF- $\kappa B-$ responsive element at $-194 \mathrm{bp}$, which presents a high homology with the transactivation site recently identified as functional in the human dio 2 promoter (Zeold et al. 2006). Thus, the responsive sequence of $\mathrm{NF}-\mathrm{\kappa B}$ in rat dio 2 promoter is probably located in a different position from the one characterized in human dio 2 promoter.

We also looked for another transcription factor candidate for D2 induction by LPS, C/EBP $\beta$, which is upregulated by LPS in glial cells (Ejarque-Ortiz et al. 2007). Furthermore, $\mathrm{C} / \mathrm{EBP}$ are crucial for regulating transcription of genes involved in some LPS responses in astrocytes (Cardinaux et al. 2000, Kelicen \& Tindberg 2004, Perez-Capote et al. 2006). Potential consensus sequences for C/EBPs appeared in mouse, rat, and human dio 2 promoter near the TSS (Song et al. 2000, Gereben et al. 2001). We found that all forms of the dio 2 promoter containing the consensus sequences were potently transactivated by C/EBPs. Morever, different $\mathrm{C} / \mathrm{EBPs}(\mathrm{C} / \mathrm{EBP} \alpha, \mathrm{C} / \mathrm{EBP} \beta$, and $\mathrm{C} / \mathrm{EBP} \delta)$ appeared able to transactivate the $\mathrm{D} 2$ rat promoter. Interestingly, knocking out $\mathrm{C} / \mathrm{EBP} \alpha$ leads to a decrease in D2 expression in brown adipose tissue (Carmona et al. 2002). Further directed mutagenesis experiments might allow us to confirm the implication of the C/EBP-binding site in the rat dio 2 promoter. Note that C/EBPs are targets for MAPK pathways (Bhat et al. 2002) that we have found implicated in D2 induction by LPS. The induction of $\mathrm{C} / \mathrm{EBP} \beta$ and $\mathrm{C} / \mathrm{EBP} \delta$ by the cAMP pathway in astrocytes (Cardinaux \& Magistretti 1996) more generally brings into question their role in the control of D2. Interestingly, $C / E B P \beta$ mRNA and $D 2$ mRNA are reported to be increased in vivo in the mediobasal hypothalamus of Japanese quail after photoperiod signal (Nakao et al. 2008).

The in vivo significance of the D2 induction by LPS in cultured astrocytes remains to be explored. The D2 induction by LPS in the tanycytes of the rat mediobasal hypothalamus increases $T_{3}$ generation, providing local negative feedback in the hypothalamus and accounting for the impaired response of the hypothalamo-pituitary-thyroid axis observed in nonthyroidal illness syndrome (Fekete et al. 2004). I.p. injection of LPS in rats also increased D2 activity in the cerebral cortex (Fekete et al. 2004). In $\mathrm{T}_{4}$-replaced thyroidectomized rats, LPS administration also increased D2 activity in the mediobasal hypothalamus but not in the cerebral cortex (Fekete et al. 2005). Hence, this suggests that the increased D2 activity in the cerebral cortex is due to falling $\mathrm{T}_{4}$ after LPS, whereas the increased D2 activity in mediobasal hypothalamus is independent of the associated fall in circulating $\mathrm{T}_{4}$.

Thyroid hormone has been shown to be critical for development and functioning of central nervous system (Bernal 2002). Paracrine signaling by glial-cell-derived $T_{3}$ activates neuronal gene expression in a co-cultured system of D2-expressing $\mathrm{H} 4$ glioma cells and D3-expressing neuroblastoma cells (Freitas et al. 2010). LPS increased D2 activity and neuronal $\mathrm{T}_{3}$-dependent gene expression in this co-cultured system (Freitas et al. 2010). The induction of D2 by LPS in primary cultures of astrocytes might represent a brain protective mechanism against inflammation. In the same way, $\mathrm{T}_{4}$, and not $\mathrm{T}_{3}$, partly protects the brain against ischemic 
stroke (D'Alecy 1997) and $T_{3}$ protects the neurones in culture from apoptosis (Muller et al. 1995). Induction of D2 activity and mRNA was also reported in the ipsilateral cortex and striatum within $24 \mathrm{~h}$ after ischemia, suggesting a neuroprotective role of D2 (Margaill et al. 2005). Ischemia increased also D3 immunoreactivity in the neurones in the cortex and hippocampus after $1 \mathrm{~h}$ (Freitas et al. 2010). However, no increase in D3 activity was observed in striatum and cortex at 6 and $24 \mathrm{~h}$ after ischemia (Margaill et al. 2005), suggesting that the initial increase in neuronal D3 immunoreactivity might be a transient regulation before $\mathrm{D} 2$ induction as observed in proximal nerve segment after peripheral nerve injury (Li et al. 2001, Courtin et al. 2005).

In conclusion, we have shown the D2 induction by LPS in primary cultures of astrocytes and specified some characteristics of D2 induction mechanism. Our observations support the possible implication of brain D2 in adaptative responses to an infectious stress.

\section{Declaration of interest}

The authors declare that there is no conflict of interest that could be perceived as prejudicing the impartiality of the research reported.

\section{Funding}

This work was supported by the Institut National de la Santé et de la Recherche Médicale, INSERM.

\section{Acknowledgements}

We are very grateful to P R Larsen (Boston, MA) for his kind gift of D2 promoter constructs. We thank M Raymondjean (Paris, France) for providing p50 NF- $\kappa \mathrm{B}, \mathrm{p} 65 \mathrm{NF}-\kappa \mathrm{B}$, and C/EBPs expression vectors and M Pomerance (Châtenay-Malabry, France) for providing LAP, LIP, and CHOP expression vectors. We also thank K Rajkowski (Le Kremlin-Bicêtre, France) for his helpful advice and the Maison des Langues (Paris Descartes University, France) for English corrections.

\section{References}

Antonio V, Brouillet A, Janvier B, Monne C, Bereziat G, Andreani M \& Raymondjean M 2002 Transcriptional regulation of the rat type IIA phospholipase $\mathrm{A}_{2}$ gene by cAMP and interleukin-1beta in vascular smooth muscle cells: interplay of the CCAAT/enhancer binding protein (C/EBP), nuclear factor-kappaB and Ets transcription factors. Biochemical Journal 368 415-424. (doi:10.1042/BJ20020658)

Baur A, Bauer K, Jarry H \& Kohrle J 2000 Effects of proinflammatory cytokines on anterior pituitary $5^{\prime}$-deiodinase type I and type II. Journal of Endocrinology 167 505-515. (doi:10.1677/joe.0.1670505)

Bernal J 2002 Action of thyroid hormone in brain. Journal of Endocrinological Investigation 25 268-288.

Bhat NR, Zhang P, Lee JC \& Hogan EL 1998 Extracellular signal-regulated kinase and $\mathrm{p} 38$ subgroups of mitogen-activated protein kinases regulate inducible nitric oxide synthase and tumor necrosis factor-alpha gene expression in endotoxin-stimulated primary glial cultures. Journal of Neuroscience 18 1633-1641.
Bhat NR, Feinstein DL, Shen Q \& Bhat AN 2002 p38 MAPK-mediated transcriptional activation of inducible nitric-oxide synthase in glial cells. Roles of nuclear factors, nuclear factor kappa B, cAMP response elementbinding protein, CCAAT/enhancer-binding protein-beta, and activating transcription factor-2. Journal of Biological Chemistry 277 29584-29592. (doi:10.1074/jbc.M204994200)

Bianco AC, Salvatore D, Gereben B, Berry MJ \& Larsen PR 2002 Biochemistry, cellular and molecular biology, and physiological roles of the iodothyronine selenodeiodinases. Endocrine Reviews 23 38-89. (doi:10.1210/er.23.1.38)

Bowman CC, Rasley A, Tranguch SL \& Marriott I 2003 Cultured astrocytes express toll-like receptors for bacterial products. Glia $\mathbf{4 3}$ 281-291. (doi:10.1002/glia.10256)

Bradford MM 1976 A rapid and sensitive method for the quantitation of microgram quantities of protein utilizing the principle of protein-dye binding. Analytical Biochemistry 72 248-254. (doi:10.1016/00032697(76)90527-3)

Cardinaux JR \& Magistretti PJ 1996 Vasoactive intestinal peptide, pituitary adenylate cyclase-activating peptide, and noradrenaline induce the transcription factors CCAAT/enhancer binding protein (C/EBP)-beta and $\mathrm{C} / \mathrm{EBP}$ delta in mouse cortical astrocytes: involvement in cAMP-regulated glycogen metabolism. Journal of Neuroscience 16 919-929.

Cardinaux JR, Allaman I \& Magistretti PJ 2000 Pro-inflammatory cytokines induce the transcription factors C/EBPbeta and C/EBPdelta in astrocytes. Glia 29 91-97. (doi:10.1002/(SICI)1098-1136(20000101)29:1<91:: AID-GLIA9 > 3.0.CO;2-I)

Carmona MC, Iglesias R, Obregon MJ, Darlington GJ, Villarroya F \& Giralt M 2002 Mitochondrial biogenesis and thyroid status maturation in brown fat require CCAAT/enhancer-binding protein alpha. Journal of Biological Chemistry 277 21489-21498. (doi:10.1074/jbc. M201710200)

Chen LF \& Greene WC 2004 Shaping the nuclear action of NF-kappaB. Nature Reviews. Molecular Cell Biology 5 392-401. (doi:10.1038/nrm1368)

Courtin F, Chantoux F \& Francon J 1986 Thyroid hormone metabolism by glial cells in primary culture. Molecular and Cellular Endocrinology $\mathbf{4 8}$ 167-178. (doi:10.1016/0303-7207(86)90039-0)

Courtin F, Chantoux F, Gavaret JM, Toru-Delbauffe D, Jacquemin C \& Pierre M 1989 Induction of type II $5^{\prime}$-deiodinase activity in cultured rat astroglial cells by $12-O$-tetradecanoylphorbol-13-acetate: dependence on glucocorticoids. Endocrinology 125 1277-1281. (doi:10.1210/endo-125-3-1277)

Courtin F, Zrouri H, Lamirand A, Li WW, Mercier G, Schumacher M, Goascogne CL \& Pierre M 2005 Thyroid hormone deiodinases in the central and peripheral nervous system. Thyroid 15 931-942. (doi:10.1089/thy.2005.15.931)

Crantz FR, Silva JE \& Larsen PR 1982 An analysis of the sources and quantity of 3,5,3'-triiodothyronine specifically bound to nuclear receptors in rat cerebral cortex and cerebellum. Endocrinology 110 367-375. (doi:10.1210/endo-110-2-367)

D'Alecy LG 1997 Thyroid hormone in neural rescue. Thyroid 7 115-124. (doi:10.1089/thy.1997.7.115)

De Bosscher K, Vanden Berghe W \& Haegeman G 2003 The interplay between the glucocorticoid receptor and nuclear factor-kappaB or activator protein-1: molecular mechanisms for gene repression. Endocrine Reviews 24 488-522. (doi:10.1210/er.2002-0006)

Ejarque-Ortiz A, Medina MG, Tusell JM, Perez-Gonzalez AP, Serratosa J \& Saura J 2007 Upregulation of CCAAT/enhancer binding protein beta in activated astrocytes and microglia. Glia 55 178-188. (doi:10.1002/glia. 20446)

Esfandiari A, Courtin F, Lennon AM, Gavaret JM \& Pierre M 1992 Induction of type III deiodinase activity in astroglial cells by thyroid hormones. Endocrinology 131 1682-1688. (doi:10.1210/en.131.4.1682)

Esfandiari A, Gagelin C, Gavaret JM, Pavelka S, Lennon AM, Pierre M \& Courtin F 1994 Induction of type III-deiodinase activity in astroglial cells by retinoids. Glia 11 255-261. (doi:10.1002/glia.440110306)

Fekete C, Gereben B, Doleschall M, Harney JW, Dora JM, Bianco AC, Sarkar S, Liposits Z, Rand W, Emerson C et al. 2004 Lipopolysaccharide induces 
type 2 iodothyronine deiodinase in the mediobasal hypothalamus: implications for the nonthyroidal illness syndrome. Endocrinology 145 1649-1655. (doi:10.1210/en.2003-1439)

Fekete C, Sarkar S, Christoffolete MA, Emerson CH, Bianco AC \& Lechan RM 2005 Bacterial lipopolysaccharide (LPS)-induced type 2 iodothyronine deiodinase (D2) activation in the mediobasal hypothalamus (MBH) is independent of the LPS-induced fall in serum thyroid hormone levels. Brain Research 1056 97-99. (doi:10.1016/j.brainres.2005.07.021)

Freitas BC, Gereben B, Castillo M, Kallo I, Zeold A, Egri P, Liposits Z, Zavacki AM, Maciel RM, Jo S et al. 2010 Paracrine signaling by glial cellderived triiodothyronine activates neuronal gene expression in the rodent brain and human cells. Journal of Clinical Investigation 120 2206-2217. (doi:10.1172/JCI41977)

Gereben B, Salvatore D, Harney JW, Tu HM \& Larsen PR 2001 The human, but not rat, dio2 gene is stimulated by thyroid transcription factor-1 (TTF-1). Molecular Endocrinology 15 112-124. (doi:10.1210/me.15.1.112)

Gereben B, Zeold A, Dentice M, Salvatore D \& Bianco AC 2008 Activation and inactivation of thyroid hormone by deiodinases: local action with general consequences. Cellular and Molecular Life Sciences 65 570-590. (doi:10.1007/s00018-007-7396-0)

Grimaldi M, Navarra P, Pozzoli G, Preziosi P \& Schettini G 1998 Bacterial lipopolysaccharide increases interleukin- 6 and prostaglandin release in rat cortical type I astrocytes by different mechanisms: role of anti-inflammatory agents. Biochemical and Biophysical Research Communications 250 798-804. (doi:10.1006/bbrc.1998.9378)

Guadano-Ferraz A, Obregon MJ, St Germain DL \& Bernal J 1997 The type 2 iodothyronine deiodinase is expressed primarily in glial cells in the neonatal rat brain. PNAS 94 10391-10396. (doi:10.1073/pnas.94.19. 10391)

Heurtaux T, Benani A, Moulin D, Muller N, Netter P \& Minn A 2006 Induction of UGT1A6 isoform by inflammatory conditions in rat astrocytes. Neuropharmacology 50 317-328. (doi:10.1016/j.neuropharm. 2005.09.007)

Jung-Testas I \& Baulieu EE 1984 Anti-steroid action in cultured L-929 mouse fibroblasts. Journal of Steroid Biochemistry 20 301-306. (doi:10.1016/00224731(84)90221-8)

Kelicen P \& Tindberg N 2004 Lipopolysaccharide induces CYP2E1 in astrocytes through MAP kinase kinase-3 and C/EBPbeta and -delta. Journal of Biological Chemistry 279 15734-15742. (doi:10.1074/jbc. M311850200)

Kozuka N, Kudo Y \& Morita M 2007 Multiple inhibitory pathways for lipopolysaccharide- and pro-inflammatory cytokine-induced nitric oxide production in cultured astrocytes. Neuroscience 144 911-919. (doi:10.1016/ j.neuroscience.2006.10.040)

Lamirand A, Mercier G, Ramauge M, Pierre M \& Courtin F 2007 Hypoxia stabilizes type 2 deiodinase activity in rat astrocytes. Endocrinology 148 4745-4753. (doi:10.1210/en.2007-0625)

Lamirand A, Pallud-Mothre S, Ramauge M, Pierre M \& Courtin F 2008 Oxidative stress regulates type 3 deiodinase and type 2 deiodinase in cultured rat astrocytes. Endocrinology 149 3713-3721. (doi:10.1210/en. 2007-1462)

Lee WJ, Shin CY, Yoo BK, Ryu JR, Choi EY, Cheong JH, Ryu JH \& Ko KH 2003 Induction of matrix metalloproteinase-9 (MMP-9) in lipopolysaccharide-stimulated primary astrocytes is mediated by extracellular signalregulated protein kinase 1/2 (Erk1/2). Glia 41 15-24. (doi:10.1002/glia. 10131)

Lennon AM, Ramauge M, Dessouroux A \& Pierre M 2002 MAP kinase cascades are activated in astrocytes and preadipocytes by 15 -deoxyDelta(12-14)-prostaglandin J(2) and the thiazolidinedione ciglitazone through peroxisome proliferator activator receptor gamma-independent mechanisms involving reactive oxygenated species. Journal of Biological Chemistry 277 29681-29685. (doi:10.1074/jbc.M201517200)

Li WW, Le Goascogne C, Ramauge M, Schumacher M, Pierre M \& Courtin F 2001 Induction of type 3 iodothyronine deiodinase by nerve injury in the rat peripheral nervous system. Endocrinology 142 5190-5197. (doi:10.1210/ en.142.12.5190)
Lucas SM, Rothwell NJ \& Gibson RM 2006 The role of inflammation in CNS injury and disease. British Journal of Pharmacology 147 (Supplement 1) S232-S240. (doi:10.1038/sj.bjp.0706400)

Margaill I, Royer J, Lerouet D, Ramauge M, Le Goascogne C, Li WW, Plotkine M, Pierre M \& Courtin F 2005 Induction of type 2 iodothyronine deiodinase in astrocytes after transient focal cerebral ischemia in the rat. Journal of Cerebral Blood Flow and Metabolism 25 468-476. (doi:10.1038/sj. jcbfm.9600041)

Massaad C, Garlatti M, Wilson EM, Cadepond F \& Barouki R 2000a A natural sequence consisting of overlapping glucocorticoid-responsive elements mediates glucocorticoid, but not androgen, regulation of gene expression. Biochemical Journal 350 123-129. (doi:10.1042/02646021:3500123)

Massaad C, Paradon M, Jacques C, Salvat C, Bereziat G, Berenbaum F \& Olivier JL $2000 b$ Induction of secreted type IIA phospholipase $\mathrm{A}_{2}$ gene transcription by interleukin-1beta. Role of C/EBP factors. Journal of Biological Chemistry 275 22686-22694. (doi:10.1074/jbc. M001250200)

Morrison RS \& de Vellis J 1981 Growth of purified astrocytes in a chemically defined medium. PNAS 78 7205-7209. (doi:10.1073/pnas.78.11.7205)

Muller Y, Rocchi E, Lazaro JB \& Clos J 1995 Thyroid hormone promotes BCL-2 expression and prevents apoptosis of early differentiating cerebellar granule neurons. International Journal of Developmental Neuroscience 13 871-885. (doi:10.1016/0736-5748(95)00057-7)

Nakao N, Ono H, Yamamura T, Anraku T, Takagi T, Higashi K, Yasuo S, Katou Y, Kageyama S, Uno Y et al. 2008 Thyrotrophin in the pars tuberalis triggers photoperiodic response. Nature 452 317-322. (doi:10.1038/ nature06738)

Pallud S, Ramauge M, Gavaret JM, Lennon AM, Munsch N, St Germain DL, Pierre M \& Courtin F 1999 Regulation of type 3 iodothyronine deiodinase expression in cultured rat astrocytes: role of the Erk cascade. Endocrinology 140 2917-2923. (doi:10.1210/en.140.6.2917)

Pawate S, Shen Q, Fan F \& Bhat NR 2004 Redox regulation of glial inflammatory response to lipopolysaccharide and interferongamma. Journal of Neuroscience Research 77 540-551. (doi:10.1002/jnr.20180)

Perez-Capote K, Saura J, Serratosa J \& Sola C 2006 Expression of C/EBPalpha and $\mathrm{C} / \mathrm{EBP}$ beta in glial cells in vitro after inducing glial activation by different stimuli. Neuroscience Letters 410 25-30. (doi:10.1016/j.neulet. 2006.09.078)

Pomerance M, Mockey M, Young J, Quillard J \& Blondeau JP 2005 Expression, hormonal regulation, and subcellular localization of CCAA$\mathrm{T} /$ enhancer-binding protein-beta in rat and human thyrocytes. Thyroid $\mathbf{1 5}$ 197-204. (doi:10.1089/thy.2005.15.197)

Rada B \& Leto TL 2008 Oxidative innate immune defenses by Nox/Duox family NADPH oxidases. Contributions to Microbiology 15 164-187. (doi:10. 1159/000136357)

Sanchez E, Singru PS, Fekete C \& Lechan RM 2008 Induction of type 2 iodothyronine deiodinase in the mediobasal hypothalamus by bacterial lipopolysaccharide: role of corticosterone. Endocrinology 149 2484-2493. (doi:10.1210/en.2007-1697)

Shin CY, Lee WJ, Choi JW, Choi MS, Park GH, Yoo BK, Han SY, Ryu JR, Choi EY \& Ko KH 2007 Role of p38 MAPK on the down-regulation of matrix metalloproteinase-9 expression in rat astrocytes. Archives of Pharmacal Research 30 624-633. (doi:10.1007/BF02977658)

Song S, Adachi K, Katsuyama M, Sorimachi K \& Oka T 2000 Isolation and characterization of the $5^{\prime}$-upstream and untranslated regions of the mouse type II iodothyronine deiodinase gene. Molecular and Cellular Endocrinology 165 189-198. (doi:10.1016/S0303-7207(00)00246-X)

Sorrells SF, Caso JR, Munhoz CD \& Sapolsky RM 2009 The stressed CNS: when glucocorticoids aggravate inflammation. Neuron 64 33-39. (doi:10.1016/j.neuron.2009.09.032)

Sternberg EM 2001 Neuroendocrine regulation of autoimmune/inflammatory disease. Journal of Endocrinology 169 429-435. (doi:10.1677/joe.0. 1690429)

Sweet MJ \& Hume DA 1996 Endotoxin signal transduction in macrophages. Journal of Leukocyte Biology 60 8-26. 
Tilders FJ, DeRijk RH, Van Dam AM, Vincent VA, Schotanus K \& Persoons JH 1994 Activation of the hypothalamus-pituitary-adrenal axis by bacterial endotoxins: routes and intermediate signals. Psychoneuroendocrinology 19 209-232. (doi:10.1016/0306-4530(94)90010-8)

Tournier C, Thomas G, Pierre J, Jacquemin C, Pierre M \& Saunier B 1997 Mediation by arachidonic acid metabolites of the $\mathrm{H}_{2} \mathrm{O}_{2}-$ induced stimulation of mitogen-activated protein kinases (extracellularsignal-regulated kinase and c-Jun $\mathrm{NH}_{2}$-terminal kinase). European Journal of Biochemistry 244 587-595. (doi:10.1111/j.1432-1033.1997. 00587.x)

Tu HM, Kim SW, Salvatore D, Bartha T, Legradi G, Larsen PR \& Lechan RM 1997 Regional distribution of type 2 thyroxine deiodinase messenger ribonucleic acid in rat hypothalamus and pituitary and its regulation by thyroid hormone. Endocrinology 138 3359-3368. (doi:10.1210/en.138. 8.3359)

Zeold A, Doleschall M, Haffner MC, Capelo LP, Menyhert J, Liposits Z, da Silva WS, Bianco AC, Kacskovics I, Fekete C et al. 2006
Characterization of the nuclear factor-kappa $B$ responsiveness of the human dio2 gene. Endocrinology 147 4419-4429. (doi:10.1210/en. 2005-1608)

Zlokovic BV 1995 Cerebrovascular permeability to peptides: manipulations of transport systems at the blood-brain barrier. Pharmaceutical Research 12 1395-1406. (doi:10.1023/A:1016254514167)

Zou L, Burmeister LA, Styren SD, Kochanek PM \& DeKosky ST 1998 Up-regulation of type 2 iodothyronine deiodinase mRNA in reactive astrocytes following traumatic brain injury in the rat. Journal of Neurochemistry 71 887-890. (doi:10.1046/j.1471-4159.1998.71020887.x)

Received in final form 7 October 2010

Accepted 10 November 2010

Made available online as an Accepted Preprint 10 November 2010 